\title{
Oceanic heat transport onto the Amundsen Sea shelf through a submarine glacial trough
}

\author{
Dziga P. Walker, ${ }^{1}$ Mark A. Brandon, ${ }^{1}$ Adrian Jenkins, ${ }^{2}$ John T. Allen, ${ }^{3}$ \\ Julian A. Dowdeswell, ${ }^{4}$ and Jeff Evans ${ }^{4}$ \\ Received 13 September 2006; revised 17 November 2006; accepted 1 December 2006; published 16 January 2007.
}

[1] Glaciers which drain the West Antarctic Ice Sheet (WAIS) into the Amundsen Sea are accelerating and thinning rapidly. These observations have been attributed to the regional oceanography whereby heat contained within Circumpolar Deep Water (CDW) drives the basal melting of floating glaciers. On the basis of new data we calculate that 2.8 terra-Watts $\left(10^{12}\right)$ of oceanic heat flow onto the continental shelf and toward the glaciers via a submarine glacial trough. This is enough to account for most of the basal melting in the entire region suggesting the ocean is supplying an excess of heat toward the Antarctic continent. Citation: Walker, D. P., M. A. Brandon, A. Jenkins, J. T. Allen, J. A. Dowdeswell, and J. Evans (2007), Oceanic heat transport onto the Amundsen Sea shelf through a submarine glacial trough, Geophys. Res. Lett., 34, L02602, doi:10.1029/2006GL028154.

\section{Introduction}

[2] The marine West Antarctic Ice Sheet (WAIS) is thought to be more sensitive to external forcing than its terrestrial counterpart in East Antarctica [Oppenheimer, 1998; Thomas et al., 2004]. Although complete WAIS deglaciation is unlikely in the next few centuries, it would raise global sea level by 5-6 m [Church et al., 2001; Vaughan and Spouge, 2002] and therefore is of global significance. Some of the largest drainage basins of the WAIS support glaciers that flow into the Amundsen Sea Embayment where they end as floating ice tongues and shelves with very deep $(>1000 \mathrm{~m})$ sub-ice water-filled cavities [Stenoien and Bentley, 2000; Thomas et al., 2004; Holt et al., 2006; Vaughan et al., 2006]. All of the ice shelves here (Figure 1) are consistent in showing thinning [Shepherd et al., 2004] and this thinning is observed in the glaciers further upstream from the ice shelves. The primary glaciers are fed by numerous tributaries deeper within the interior of the WAIS [Bamber et al., 2000; Vaughan et al., 2001]. The most widely studied of these glaciers, the Pine Island Glacier, exhibits very large basal melt rates [Jacobs et al., 1996; Jenkins et al., 1997; Hellmer et al., 1998; Rignot and Jacobs, 2002; Thomas et al., 2004], and a retreating grounding line [Rignot, 1998], both of which imply a negative mass balance at the seaward end of the

\footnotetext{
${ }^{1}$ Centre for Earth, Planetary, Space and Astronomical Research, Open University, Milton Keynes, England.

${ }^{2}$ British Antarctic Survey, Cambridge, England.

${ }^{3}$ National Oceanography Centre, University of Southampton, Waterfront Campus, Southampton, England.

${ }^{4}$ Scott Polar Research Institute, University of Cambridge, Cambridge, England.
}

Copyright 2007 by the American Geophysical Union. 0094-8276/07/2006GL028154 glacier. Whilst the ocean is thought to be the key driver responsible for these changes [Jacobs et al., 1996; Jenkins et al., 1997; Rignot, 1998; Hellmer et al., 1998; Payne et al., 2004; Shepherd et al., 2004], the quantification of this oceanic forcing has proved difficult. The main reasons being the remote location and because perennial sea ice prevents easy access to the waters of the Amundsen Sea Embayment.

[3] To date, the only oceanographic data collected at the ice front of Pine Island Glacier (PIG) and within the Amundsen Sea Embayment showed the presence of almost undiluted Circumpolar Deep Water (CDW) beneath the pycnocline [Jacobs et al., 1996; Jenkins et al., 1997; Hellmer et al., 1998]. This CDW was more than $3^{\circ} \mathrm{C}$ above the in-situ freezing point and was able to flow beneath the floating portion of PIG, and so drive basal melting. Resulting dilution by the glacial melt drives a circulation whereby fresher and cooler modified CDW flows up the underside of the floating ice shelves and returns to the open sea higher in the water column [Hellmer et al., 1998].

[4] CDW is the most voluminous global water mass and is a key component of the Antarctic Circumpolar Current (ACC) [Orsi et al., 1999]. The southern boundary of the ACC (SBACC) is defined as the poleward limit of CDW, and while showing temporal and spatial variability, it is generally not found close to the continental shelf break of Antarctica [Orsi et al., 1995]. In the Amundsen and Bellingshausen seas and west of the Antarctic Peninsula the SBACC does reach the continental margin and so CDW is relatively close to the shelf break [Orsi et al., 1995; Hofmann et al., 1996; Whitworth III et al., 1998]. This alone is not enough to enable the warm waters to reach the floating ice shelves of the Amundsen Sea because the continental shelf acts as a topographic barrier for the majority of the deep water. Thus the height of the offshore CDW in the water column and the height of the shelf edge are crucial in determining whether CDW can flow onto the shelf. Any significant depression in the shelf edge for example within a glacial trough would permit a thicker layer of undiluted CDW onto the shelf. In this paper we use conductivity-temperature-depth (CTD) data to show a region where CDW can easily cross the shelf break and approach the PIG and we calculate how much heat it could supply for basal ice-shelf melting.

\section{Results and Discussion}

[5] In March 2003 an oceanographic survey was conducted at the shelf break of the Amundsen Sea to the northwest of the Amundsen Sea Embayment (Figure 1). This survey was centered over a submarine glacial trough 


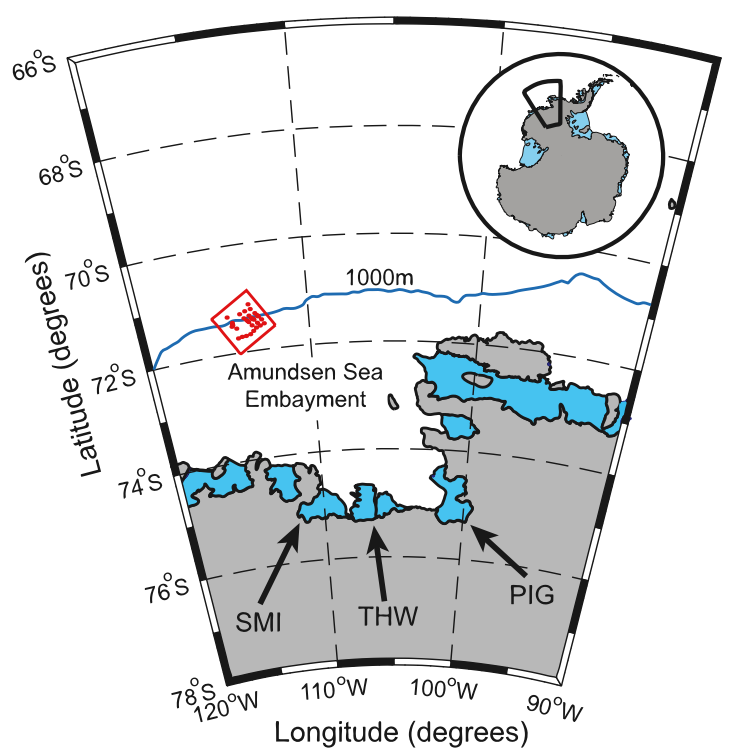

Figure 1. The Amundsen Sea Embayment with positions of major fast-flowing glaciers draining the West Antarctic Ice Sheet is shown. The blue contour is the $1000 \mathrm{~m}$ contour. PIG is the Pine Island Glacier, THW is the Thwaites Glacier, and SMI is the Smith Glacier. The survey region and conductivity-temperature-depth (CTD) locations are shown in red. Blue shading denotes floating ice shelves.

(Figure 2) which cut across the shelf break in a region where it dips to around $600 \mathrm{~m}$ below sea level for a distance of approximately $40 \mathrm{~km}$. The upper boundary of CDW in the Amundsen Sea is defined as the $28.00 \mathrm{~kg} \mathrm{~m}^{-3}$ neutral density $\left(\gamma^{\mathrm{n}}\right)$ surface [Whitworth III et al., 1998], and CTD data collected on our survey show clearly that above the trough (Figure 3 ) this upper boundary is in the depth range $360-430 \mathrm{~m}$. The trough itself is filled with CDW and therefore provides an easy access route for large volumes of warm CDW onto the shelf. From the shelf break the trough trends southeast across the continental shelf toward Pine Island Glacier [Evans et al., 2006]. From here another

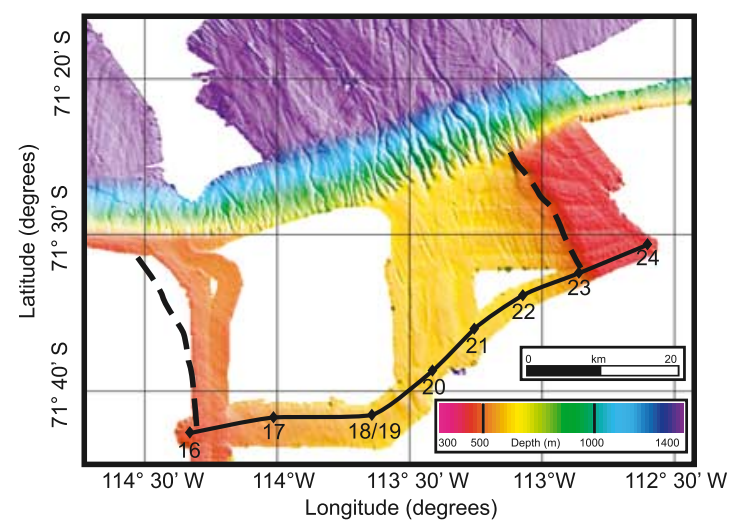

Figure 2. Swath bathymetry showing the shelf break and the submarine glacial trough (dashed lines) [Dowdeswell et al., 2006; Evans et al., 2006]. A non-linear color scheme is used to clearly show the trough features, and depths $>1400 \mathrm{~m}$ are colored the same. The black line is the CTD transect shown in Figure 3.
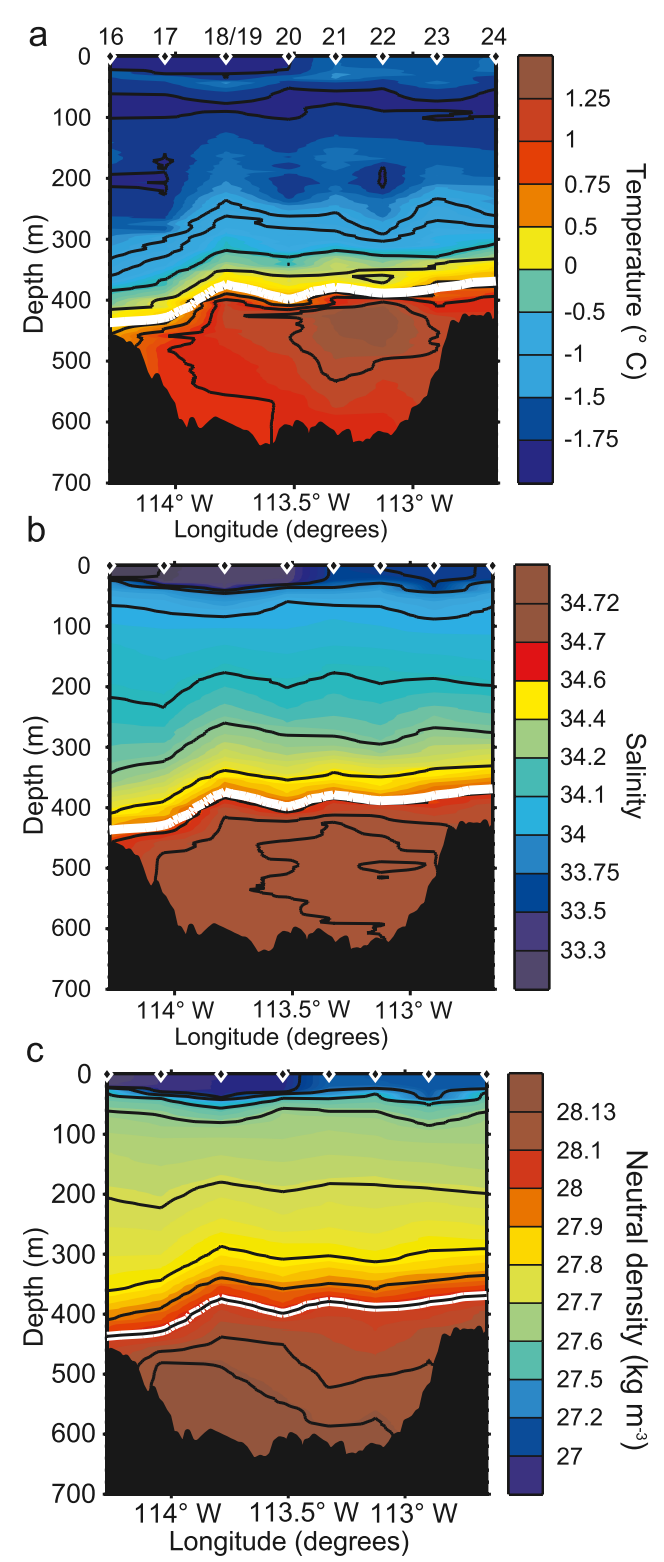

Figure 3. Hydrographic data measured across the glacial trough. (a) Temperature, (b) salinity, and (c) neutral density $\gamma^{\mathrm{n}}$. The white line is the upper limit of Circumpolar Deep Water $(\mathrm{CDW})\left(\gamma^{\mathrm{n}}=28.00 \mathrm{~kg} \mathrm{~m}^{-3}\right)$. The black diamonds are the CTD positions with their associated numbers (located in Figure 2).

glacial trough connects to the deep water region in front of and beneath PIG and Thwaites Glacier [Jacobs et al., 1996; Lowe and Anderson, 2002]. The troughs provide a major route for $\mathrm{CDW}$ to access the ice shelves of the Amundsen Sea Embayment, some $500 \mathrm{~km}$ inshore of the shelf break.

[6] We used the data in Figure 3 to derive a transport rate for the CDW into this trough. First, we derived relative geostrophic velocity profiles between each CTD station pair along a synoptic section across the glacial trough and then referenced the relative velocities to absolute currents determined from shipboard Acoustic Doppler Current Profiler (ADCP) data that had been filtered and de-tided using a 


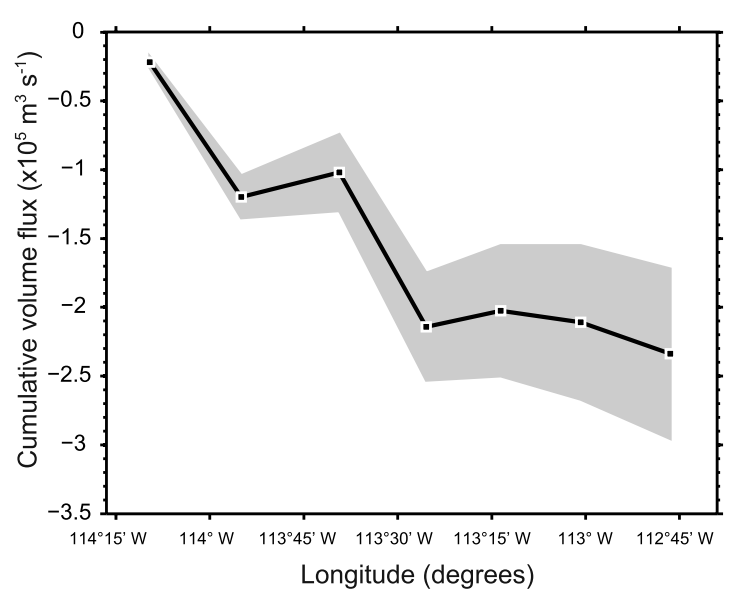

Figure 4. The cumulative volume flux of CDW through the trough. Negative values are poleward (on-shelf) flowing water. The $95 \%$ confidence limits (shaded gray) are calculated using the standard error of the mean derived from the sections of Acoustic Doppler Current Profiler data used in the volume flux calculation.

harmonic analysis technique with spatially dependent polynomials [Allen, 1995].

[7] Transport rates derived from the CTD section across the glacial trough give a volume flux of CDW $\left(\gamma^{\mathrm{n}}>28.00 \mathrm{~kg} \mathrm{~m}^{-3}\right)$ into the trough of $234 \mathrm{mSv}( \pm 62 \mathrm{mSv}$, $95 \%$ CI, Figure 4). This figure is comparable to the estimated inflow beneath $800 \mathrm{~m}$ at the PIG ice front of $172 \mathrm{mSv}$ [Jacobs et al., 1996]. If we take temperature relative to the surface freezing point of CDW, we can obtain a heat transport representing the amount of energy available for melting ice. We calculate $2.8 \mathrm{TW}( \pm 0.68 \mathrm{TW})$ of heat is flowing toward the Antarctic continent in the trough. If we make the assumptions that none of this heat was lost en-route to the sub-ice cavities, and that all of it was used for basal melting of the ice shelves, then the meltwater return flux would be $8200 \mathrm{~m}^{3} \mathrm{~s}^{-1}$ or $257 \mathrm{~km}^{3}$ year $^{-1}$ (Gt year ${ }^{-1}$ ). This is slightly greater than the entire glacial discharge into the south-eastern Amundsen Sea from Pine Island, Thwaites, and Smith glaciers combined [Rignot and Thomas, 2002]. Given that some of this discharge is lost through iceberg calving, the heat carried on-shelf within the trough is sufficient to account for a significant portion of the entire ice shelf melting in the Amundsen Sea.

[8] Our first assumption is realistic given that at PIG the average temperature of CDW flowing beneath $700 \mathrm{~m}$ at the ice shelf front was $1.054^{\circ} \mathrm{C}$ [Hellmer et al., 1998] and the average CDW temperature $\left(\gamma^{\mathrm{n}}>28.00 \mathrm{~kg} \mathrm{~m}^{-3}\right)$ crossing the shelf break within the trough in this study was $1.057^{\circ} \mathrm{C}$. However, the shallower return flow at PIG was only $0.5^{\circ} \mathrm{C}$ cooler, on average, than the inflow [Hellmer et al., 1998] and so only a fraction of the heat getting to the glacier is used in the basal melting of the PIG ice shelf. Even this $0.5^{\circ} \mathrm{C}$ cooling of the inflow represents a heat loss equivalent to $44 \mathrm{~km}^{3}$ year ${ }^{-1}$ of melting and is close to the higher previous estimates of melting beneath PIG [Jacobs et al., 1996; Jenkins et al., 1997; Payne et al., 2004]. Although unproven, the less dense, meltwater plume from the Amundsen Sea glaciers may hug the continent and flow westward in a coastal current. Such a current would flow into the southern limb of the Ross Sea where Jacobs et al.
[2002] related an observed freshening to meltwater arriving from the Amundsen Sea.

[9] Despite being unable to measure longer term or seasonal variability, we argue that because there is no other water mass denser or as dense as CDW anywhere in the vicinity, and that there are no other likely mechanisms capable of producing such water masses, then there will not be a barrier capable of preventing isopycnal flow of CDW onto the shelf where topography allows. The Winter Water measured here ( $\sim 90 \mathrm{~m}$ deep, Figure 3$)$ has a salinity of 34.00 and consequently is much less dense (and so shallower) than Winter Water typically found elsewhere around Antarctica. This means that, during the austral winter, vertical convection of the water column due to salinization at the sea surface produced by sea ice formation is not strong enough to penetrate into the CDW layer. The relatively small set of summertime observational data from 1994, 2000, 2003 and 2006 (the only on-shelf oceanographic data that exist) clearly show CDW at the same high temperatures $\left(\sim 1.0-1.2^{\circ} \mathrm{C}\right)$ all along the shelf break and further on-shelf suggesting that sea ice production during this period is not as strong relative to other regions around Antarctica. The remaining important factor controlling the variability of heat transport to the ice is the proximity of the "source" undiluted CDW carried within the ACC to the shelf edge. Without any continuous measurements at the continental margin it has not been determined how variable these source waters are. One factor capable of controlling the position and strength of upwelling CDW is the Antarctic Divergence which is a wind driven feature; therefore atmospheric forcing in the South Pacific may play a role in controlling heat transport onto the shelf. Our CDW inflow can certainly explain the currently observed high glacier melt rates. If the oceanic conditions at the continental margin have remained similar over long timescales, persistent undiluted CDW present at the shelf edge could help explain why the ice shelf fronts in the south east Pacific have significantly retreated relative to their positions at the last glacial maximum.

\section{Summary}

[10] Our measurements reveal an on-shelf transport of 2.8 TW of heat within a trough. This heat is sufficient to explain most of the glacial melting that is currently estimated to be happening in the Amundsen Sea. It is however not the only source of CDW on the shelf. Indeed, Figure 3 also shows that a smaller amount of CDW flows onto the shelf in a thinner layer $(\sim 70 \mathrm{~m})$ outside of the trough. Furthermore, there are other depressions known to exist in the shelf edge further to the east of this trough thus providing more routes for heat to be carried on shelf. Given that all of the historical data measured elsewhere along the shelf edge of the Amundsen Sea (with or without a trough present) show this thin layer of warm water penetrating the shelf, it is sensible to assume that beneath the pycnocline, the Amundsen Sea shelf is flooded with relatively warm water particularly over deeper topography including that underneath the ice shelves. With such a large surplus of oceanic heat available for melting it remains to determine the physical processes that regulate its delivery to the ice shelves. 
[11] Acknowledgments. We wish to thank the officers and crew of the RRS James Clark Ross and are grateful to Stan Jacobs and Tom Kellogg for supplying information on the topography of the Amundsen Sea continental shelf break that indicated the location of the submarine trough. We are also grateful to Stan Jacobs and two anonymous reviewers for helpful comments on this manuscript. This work was funded by the Natural Environment Research Council's Autosub Under Ice Thematic Programme (award reference NER/T/S/2000/00987).

\section{References}

Allen, J. T. (1995), Subtidal and tidal currents in the vicinity of the IcelandFaeroes front, J. Atmos. Oceanic Technol., 12(3), 567-588.

Bamber, J. L., D. G. Vaughan, and I. Joughin (2000), Widespread complex flow in the interior of the Antarctic ice sheet, Science, 287(5456), 12481250.

Church, J. A., J. M. Gregory, P. Huybrechts, M. Kuhn, K. Lambeck, M. T. Nhuan, D. Qin, and P. L. Woodworth (2001), Changes in sea level, in Climate Change 2001: The Scientific Basis, edited by J. T. Houghton, et al., pp.369-693, Cambridge Univ. Press, New York.

Dowdeswell, J. A., J. Evans, C. Ó. Cofaigh, and J. B. Anderson (2006), Morphology and sedimentary processes on the continental slope off Pine Island Bay, Amundsen Sea, west Antarctica, Geol. Soc. Am. Bull., 18(5-6), 606-619, doi:10.1130/B25791.1.

Evans, J., J. A. Dowdeswell, C. Ó. Cofaigh, T. J. Benham, and J. B. Anderson (2006), Extent and dynamics of the West Antarctic Ice Sheet on the outer continental shelf of Pine Island Bay, Amundsen Sea, during the last glaciation, Mar. Geol., 230(1-2), 53-72.

Hellmer, H. H., S. S. Jacobs, and A. Jenkins (1998), Oceanic erosion of a floating Antarctic glacier in the Amundsen Sea, in Ocean, Ice, and Atmosphere: Interactions at the Antarctic Continental Margin, Antarct. Res. Ser, vol. 75, edited by S. S. Jacobs and R. F. Weiss, pp.83-99, AGU, Washington, D. C.

Hofmann, E. E., J. M. Klinck, C. M. Lascara, and D. A. Smith (1996), Water mass distribution and circulation west of the Antarctic Peninsula and including Bransfield Strait, in Foundations for Ecological Research West of the Antarctic Peninsula, Antarct. Res. Ser., vol. 70, pp.61-80, AGU, Washington, D. C.

Holt, J. W., D. D. Blankenship, D. L. Morse, D. A. Young, M. E. Peters, S. D. Kempf, T. G. Richter, D. G. Vaughan, and H. F. J. Corr (2006), New boundary conditions for the West Antarctic Ice Sheet: Subglacial topography of the Thwaites and Smith Glacier catchments, Geophys. Res. Lett., 33(9), L09502, doi:10.1029/2005GL025561.

Jacobs, S. S., H. H. Hellmer, and A. Jenkins (1996), Antarctic ice sheet melting in the Southeast Pacific, Geophys. Res. Lett., 23(9), 957-960.

Jacobs, S. S., C. F. Giulivi, and P. A. Mele (2002), Freshening of the Ross Sea during the late 20th century, Science, 297(5580), 386-389.

Jenkins, A., D. G. Vaughan, S. S. Jacobs, H. H. Hellmer, and J. R. Keys (1997), Glaciological and oceanographic evidence of high melt rates beneath Pine Island Glacier, west Antarctica, J. Glaciol., 43(143), $114-121$.

Lowe, A. L., and J. B. Anderson (2002), Reconstruction of the West Antarctic Ice Sheet in Pine Island Bay during the Last Glacial Maximum and its subsequent retreat history, Quat. Sci. Rev., 21(16-17), $1879-1897$.
Oppenheimer, M. (1998), Global warming and the stability of the West Antarctic Ice Sheet, Nature, 393(6683), 325-332.

Orsi, A. H., T. Whitworth III, and W. D. Nowlin Jr. (1995), On the meridional extent and fronts of the Antarctic Circumpolar Current, Deep Sea Res., Part I, 42(5), 641-673.

Orsi, A. H., G. C. Johnson, and J. L. Bullister (1999), Circulation, mixing and production of Antarctic Bottom Water, Prog. Oceanogr., 43, 55-109.

Payne, A. J., A. Vieli, A. P. Shepherd, D. J. Wingham, and E. Rignot (2004), Recent dramatic thinning of largest West Antarctic ice stream triggered by oceans, Geophys. Res. Lett., 31(23), L23401, doi:10.1029/ 2004GL021284

Rignot, E. J. (1998), Fast recession of a west Antarctic glacier, Science, 281(5376), 549-551.

Rignot, E., and S. S. Jacobs (2002), Rapid bottom melting widespread near Antarctic ice sheet grounding lines, Science, 296(5575), 2020-2023.

Rignot, E., and R. H. Thomas (2002), Mass balance of polar ice sheets, Science, 297(5586), 1502-1506.

Shepherd, A., D. Wingham, and E. Rignot (2004), Warm ocean is eroding West Antarctic Ice Sheet, Geophys. Res. Lett., 31(23), L23402, doi:10.1029/2004GL021106.

Stenoien, M. D., and C. R. Bentley (2000), Pine Island Glacier, Antarctica: A study of the catchment using interferometric synthetic aperture radar measurements and radar altimetry, J. Geophys. Res., 105(B9), 21,76121,779 .

Thomas, R., et al. (2004), Accelerated sea-level rise from west Antarctica, Science, 306(5694), 255-258.

Vaughan, D. G., and J. R. Spouge (2002), Risk estimation of collapse of the West Antarctic Ice Sheet, Clim. Change, 52(1-2), 65-91.

Vaughan, D. G., H. F. J. Corr, A. M. Smith, A. Jenkins, C. R. Bentley, M. D. Stenoien, S. S. Jacobs, T. B. Kellogg, E. Rignot, and B. K. Lucchitta (2001), A review of Pine Island Glacier, west Antarctica: Hypotheses of instability vs. observations of change, in The West Antarctic Ice Sheet: Behavior and Environment, Antarct. Res. Ser., vol. 77, edited by R. B. Alley and R. A. Bindschadler, pp.237-256, AGU, Washington, D. C.

Vaughan, D. G., H. F. J. Corr, F. Ferraccioli, N. Frearson, A. O'Hare, D. Mach, J. W. Holt, D. D. Blankenship, D. L. Morse, and D. A. Young (2006), New boundary conditions for the West Antarctic Ice Sheet: Subglacial topography beneath Pine Island Glacier, Geophys. Res. Lett., 33(9), L09501, doi:10.1029/2005GL025588.

Whitworth, T., III, A. H. Orsi, S.-J. Kim, W. D. Nowlin Jr., and R. A. Locarnini (1998), Water masses and mixing near the Antarctic slope front, in Ocean, Ice, and Atmosphere: Interactions at the Antarctic Continental Margin, vol. 75, edited by S. S. Jacobs and R. Weiss, pp.1-27, AGU, Washington, D. C.

J. T. Allen, National Oceanography Centre, University of Southampton, Waterfront Campus, European Way, Southampton, SO14 3ZH, England.

M. A. Brandon and D. P. Walker, Centre for Earth, Planetary, Space and Astronomical Research, Open University, Walton Hall, Milton Keynes, MK7 6AA, England. (m.a.brandon@open.ac.uk)

J. A. Dowdeswell and J. Evans, Scott Polar Research Institute, University of Cambridge, Lensfield Road, Cambridge CB2 1ER, England.

A. Jenkins, British Antarctic Survey, High Cross, Madingley Road, Cambridge, CB3 0ET, England. 